Original article

\title{
Risk factors for kidney damage in COVID-19 patients admitted to the intensive care unit
}

\author{
Diana K. Sarkisian ${ }^{1}$, Natalia V. Chebotareva ${ }^{2}$, Valerie McDonnell ${ }^{2}$, Armen V. Oganesyan ${ }^{3}$, Tatyana N. Krasnova ${ }^{1}$, \\ Egor A. Makarov ${ }^{1}$
}

1 Lomonosov Moscow State University, Moscow, Russia

2 Sechenov First Moscow State Medical University, Moscow, Russia

${ }^{3}$ ZAO Group of Companies Medsi Clinical Hospital No.1, Moscow, Russia

Received 13 September 2020, Revised 24 March 2021, Accepted 4 April 2021

(C) 2020, Sarkisian D.K., Chebotareva N.V., McDonnell V., Oganesyan A.V., Krasnova T.N., Makarov E.A.

(C) 2020, Russian Open Medical Journal

Abstract: Background - Acute kidney injury (AKI) reaches $29 \%$ in the intensive care unit (ICU). Our study aimed to determine the prevalence, features, and the main AKI factors in critically ill patients with coronavirus disease 2019 (COVID-19).

Material and Methods - The study included 37 patients with COVID-19. We analyzed the total blood count test results, biochemical profile panel, coagulation tests, and urine samples. We finally estimated the markers of kidney damage and mortality.

Result - All patients in ICU had proteinuria, and $80.5 \%$ of patients had hematuria. AKI was observed in $45.9 \%$ of patients. Independent risk factors were age more than 60 years, increased C-reactive protein (CRP) level, and decreased platelet count.

Conclusion - Kidney damage was observed in most critically ill patients with COVID-19. The independent risk factors for AKI in critically ill patients were elderly age, a cytokine response with a high CRP level.

Keywords: COVID-19, proteinuria, tubular dysfunction, acute kidney injury.

Cite as Sarkisian DK, Chebotareva NV, McDonnell V, Oganesyan AV, Krasnova TN, Makarov EA. Risk factors for kidney damage in COVID-19 patients admitted to the intensive care unit. Russian Open Medical Journal 2021; 10: e0203.

Correspondence to Natalia V. Chebotareva. E-mail: natasha tcheb@mail.ru.

\section{Introduction}

Coronavirus disease 2019 (COVID-19) is a disease caused by the novel SARS-CoV-2 (severe acute respiratory syndrome-related coronavirus 2). SARS-CoV-2 is a single-stranded ribonucleic acid (RNA) virus belonging to the Coronaviridae family, $B$ lineage of the $\beta$-CoVs [1]. The first cases of COVID-19 were reported in December 2019, and the pandemic was announced in March 2020. Despite the initial damage to the respiratory system in COVID-19, many patients develop disorders in other organs, including the kidneys. Acute kidney injury (AKI) is detected in 3.6 to $22 \%$ of hospitalized patients with COVID-19, and it reaches $29 \%$ in the intensive care unit (ICU) [2-6]. Around $20 \%$ of patients admitted to an intensive care unit (ICU) with COVID-19 require renal replacement therapy (RRT) [5]. Also, the development of AKI is followed by an increase in mortality in this group of patients by 5 times, which allows us to consider it as one of the most critical unfavorable prognostic factors in COVID-19 patients [4]. The mechanisms and factors that lead to the death of patients with COVID-19 are common with those that lead to AKI. Cytokine storm, direct cytopathic action of the virus, thrombotic microangiopathy, hypoxia, activation of the renin-angiotensin-aldosterone system are considered to influence the development of AKI in COVID-19 patients [7]. Critically ill patients are usually subjected to many factors, and they develop AKI most often [6]. Our study aimed to determine the prevalence, features and the main AKI factors in critically ill patients with COVID-19.

\section{Material and Methods}

Patients

The data of patients with COVID-19 admitted to the intensive care unit of Moscow State Clinical Hospital №1 from April to May 2020 were obtained from electronic medical records. The study included 37 patients: 20 men and 17 women aged 26 to 88 years. The median (with standard deviation) of the patients' age was $61.86 \pm 15.0$ years.

Local ethics committee of the Moscow State Clinical Hospital №1 approved this research.

\section{Clinical and laboratory methods}

COVID-19 was confirmed and diagnosed on the basis of positive reverse transcriptase-polymerase chain reaction test (RT-PCR) taken by nasopharyngeal and oropharyngeal swabs or typical images of lung damage on the computed tomography (CT) scan which shows a white mist, or "ground glass," a pattern in both lungs - a characteristic sign of coronavirus. According to the percentage of lung tissue involvement, the severity of pneumonia was determined as mild (CT1) - up to $25 \%$ of the lung parenchyma involvement; moderate (CT2) - 25-50\%; severe (CT3) - 50-75\%; extremely severe (CT4) - more than $75 \%$ of the lung parenchyma involvement. The analysis also included the presence of cardiovascular diseases, including arterial hypertension, and type 2 diabetes mellitus, and uptake of specific medications (ex. hydroxychloroquine with 
azithromycin, antiviral drugs - lopinavir-ritonavir, oseltamivir, dexamethasone and tocilizumab administration, as well as nephrotoxic drugs - vancomycin, polymyxin).

We analyzed the results of the total blood count test (precisely the number of leukocytes, platelets), biochemical profile panel (indicators of urea, creatinine, potassium, sodium, chlorine, magnesium, phosphorus levels), coagulation tests (D-dimer, fibrinogen levels) and urine samples. The analysis included the maximum levels of urea, creatinine, D-dimer, C-reactive protein, ferritin and procalcitonin, maximum and minimum levels of fibrinogen, minimum levels of platelets and electrolytes (potassium, sodium, chlorine, magnesium, phosphorus) during the examination period.
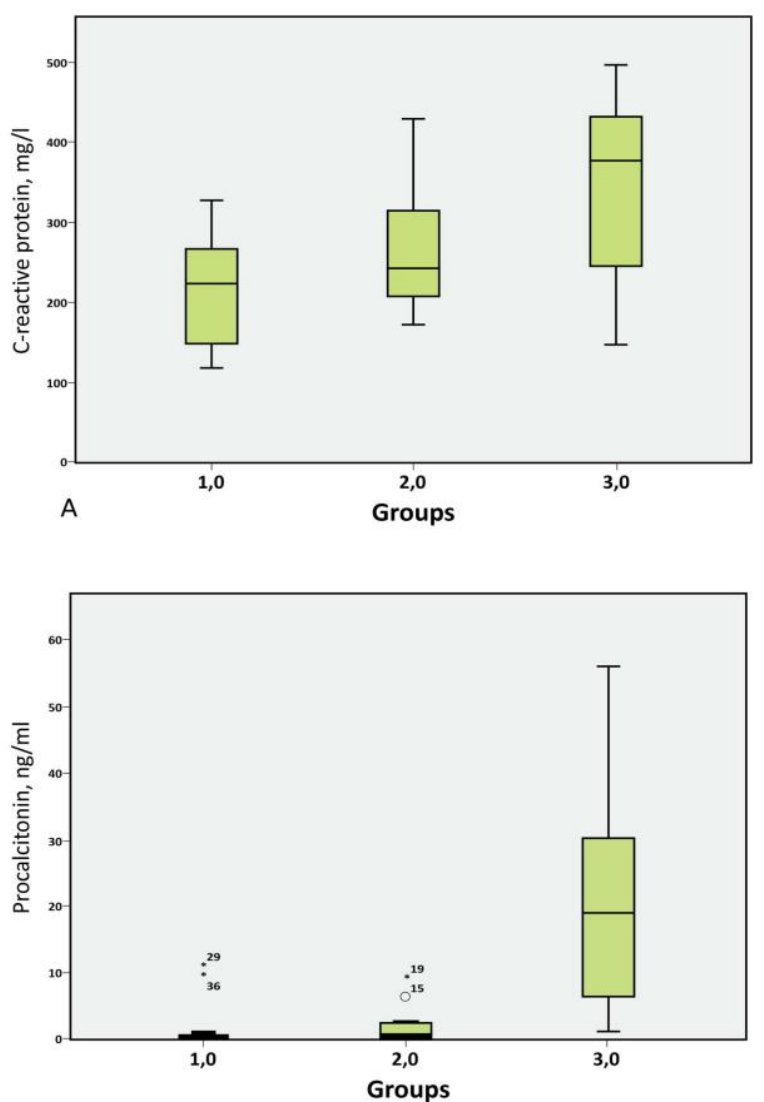

B

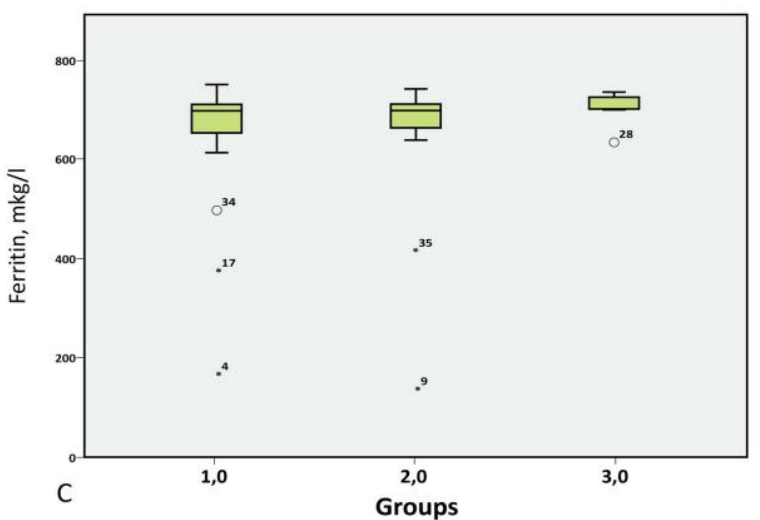

Figure 1. Inflammation factors in critically ill patients with COVID-19.

A. $p=0.0131$ vs 3 group; B. $p>0.051$ vs 2 vs 3 groups; $C$. $p=0.031$ vs 2 group $\mathrm{p}=0.0171$ vs 3 group.

\section{Definitions}

The patients were divided into three groups: group 1 included patients with no AKI, group 2 included patients with AKI stages 1-2, and group 3 included patients with severe AKI stage 3 requiring hemodialysis. AKI was defined according to the KDIGO-Clinical Practice Guideline for Acute Kidney Injury [8]: An increase in serum creatinine $(\mathrm{SCr})$ by $\geq 26.4 \mu \mathrm{mol} / \mathrm{L}(0.3 \mathrm{mg} / \mathrm{dL})$ within $48 \mathrm{~h}$, or an increase in $\mathrm{SCr}$ to $>1.5$ times baseline within the previous seven days, or urine volume $<0.5 \mathrm{~mL} / \mathrm{kg} / \mathrm{h}$ for $>6 \mathrm{~h}$.

Markers of kidney damage/AKI occurrence and mortality in COVID-19 patients were finally estimated.

\section{Statistical analysis}

The data were summarized with descriptive statistics. Results were presented as the number and percentage for categorical variables, like the median and interquartile range (IQR) - Me [IQR] for continuous variables with a non-normal distribution. Differences in proportions and continuous data were tested using the Mann-Whitney U-test, respectively. The principal components analysis and rotation method Varimax with Kaiser normalization was used for choosing the number of components to extract. Logistic regression models were used for the determining of independent risk factors of AKI. A ROC-curves for the main factors were developed. A two-sided P-value $<0.05$ was considered to indicate statistical significance. Statistical analysis was performed using IBM SPSS Statistics, version 23.

\section{Results}

\section{Renal disorders}

All patients had proteinuria: 17 (47.2\%) patients had mild proteinuria up to $1.0 \mathrm{~g} / \mathrm{l}, 19(52.8 \%)$ had moderate proteinuria from 1.0 to $2.0 \mathrm{~g} / \mathrm{l}$. Seven (53.8\%) patients in group 1, 5 (33.3\%) patients in group 2, 7 (87.5\%) patients in group 3 had moderate proteinuria.

Sixteen (44.4\%) patients had severe hematuria (2+, 3+ diagnosed by urine dipstick test), $13(36.1 \%)$ had hematuria ranging from mild to moderate ("+/-", "1+"). Six (16.7\%) patients had no sign of erythrocytes in the urine samples. Electrolyte disturbances often developed in critically ill patients. A decrease in the level of potassium, sodium, magnesium, and phosphorus in the blood serum combined with a decrease in the urine density was observed in 23 patients (62.1\%): 13 patients with normal renal function, and 10 patients with AKI stage 2-3. Hypokalemia $(3.0$ [2.7-3.2] $\mathrm{mmol} / \mathrm{l}$ ) occurred in $10(77 \%)$ patients in group 1 , in 9 $(52.9 \%)$ patients in group 2, and in $3(37.5 \%)$ patients in group 3. Hyponatremia (131 [130-133] mmol/l) was observed in 25 (67.5\%) patients. Hypomagnesemia (0.65 [0.6-0.7] mmol/l) was observed in $31 \%$ patients. Hypophosphatemia $(0.64$ [0.61-0.69] $\mathrm{mmol} / \mathrm{l})$ was noted in $50 \%$ patients.

Electrolyte disturbances were more common in patients with lowered leukocyte count 5.4 [4.56-8.21] $\times 10^{9} / \mathrm{L}$ in blood serum other than 9.12 [5.4-14.3] $\times 10^{9} / \mathrm{L}$ in blood serum of patients without electrolyte disturbances, which was confirmed by regression analysis (Supplementary material, Table 1). Other factors, including the uptake of diuretics, antiviral drugs, and nephrotoxic drugs, were not significantly associated with electrolyte disturbances (hypokalemia, hyponatremia, hypomagnesemia, hypophosphatemia). 

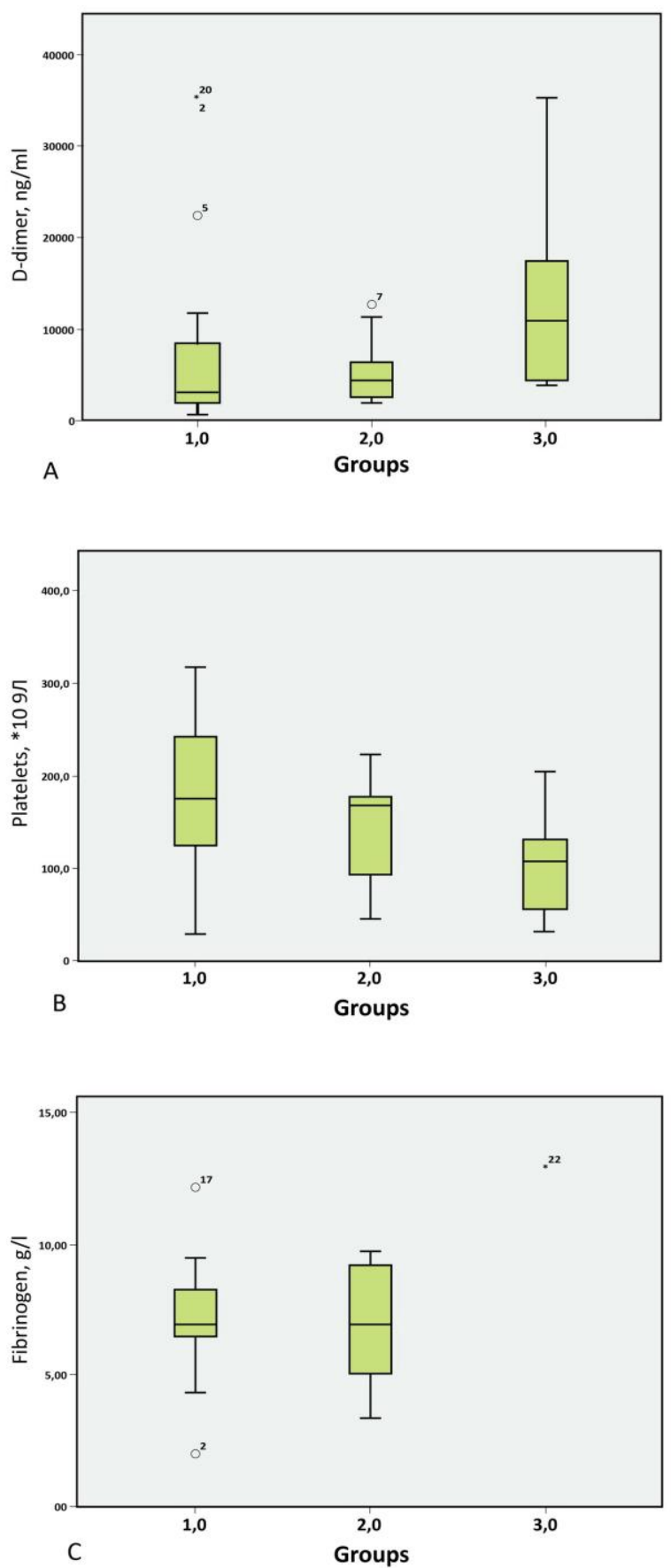

Figure 2. Hypercoagulability factors in critically ill COVID-19 patients.

A. $p<0.05$ group 1,2 vs 3 ; B. $p>0.05$ group 1 vs $3 ; C . p=0.05$ group 1 vs 2 and 3.

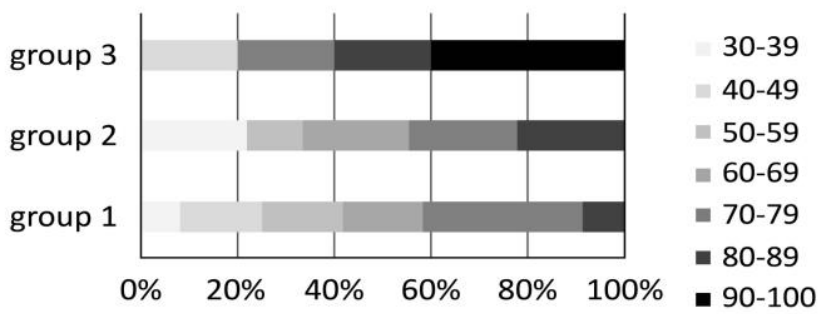

Figure 3. Lung Damage in groups of patients.
AKI, with an increase in creatinine level up to 192 [144-261] $\mu \mathrm{mol} / \mathrm{L}$ was observed in 17 (45.9\%) out of 37 critically ill patients. 8 (21.6\%) of 37 patients had AKI stage 3 (creatinine serum concentration 491 [415-661] $\mu \mathrm{mol} / \mathrm{I})$, which required hemodialysis (HD).

\section{Inflammation factors}

The C-reactive protein (CRP) levels (median 376 [166-437] $\mathrm{mg} / \mathrm{l}$ ) was significantly higher in group 3 compared to group 2 (232 [199-279] mg/l) and group 1 (231 [149-268] mg/l), $p<0.05$. The ferritin levels were increased in almost all patients without significant differences between groups (700 [672-713] $\mu \mathrm{g} / \mathrm{l})$.

High levels of procalcitonin (up to $10 \mathrm{ng} / \mathrm{ml}$ ) were detected in 3 patients on HD, 1 patient with AKI, and 1 patient without AKI. An extremely high level of procalcitonin (more than $10 \mathrm{ng} / \mathrm{ml}$ ) was observed in 4 patients on HD and 1 without AKI. If we consider the median of procalcitonin values, a statistically significant increase was noted in patients of group 3, which was characterized by an increase in procalcitonin by 10-20 times, while in patients of group 2 , the level of procalcitonin did not exceed a two-fold increase. The patients of group 1 showed the reference number of procalcitonin level within the normal range (Figure 1).

\section{Hypercoagulability factors and disseminated intravascular coagulation syndrome (DIC)}

The D-dimer level was above normal in all critically ill patients. Significantly higher values of D-dimer $11,014[4,095-26,253] \mathrm{ng} / \mathrm{ml}$ were observed in group 3 of patients with AKI requiring HD, versus group 2 4,642 [2,812-6,420] ng/ml and group $13,047[1,853-$ $8,503] \mathrm{ng} / \mathrm{ml}, \mathrm{p}<0.05$. The maximum level of $\mathrm{D}$-dimer (more than 10 times) was observed in $4(50 \%)$ patients in group 3, $5(31 \%)$ patients in group 2, and $3(23 \%)$ patients in group 1. D-dimer levels were generally elevated before AKI and continued to rise as renal function deteriorated.

The platelet count was significantly lower in group 3 (93 [55132] $\times 10^{9} / \mathrm{I}$, compared to group 2 (175 [101-178] $\left.\times 10^{9} / \mathrm{I}\right)$ and in group 1 (177 [125-242] x109/l, $p<0.05$. The median of fibrinogen level did not differ significantly between the study groups. However, an increase in the level of fibrinogen more than two times was observed only in 1 patient of group 3 compared to 8 patients in group 2 and 4 patients in group 1, which may also indicate its possible consumption during blood coagulation (Figure 2)

\section{Lung damage and underlying conditions}

According to the CT scan results, 6 (16.7\%) patients had a picture of $\mathrm{CT} 2,18(47.2 \%)$ patients had a picture of $\mathrm{CT} 3$, and 13 (36.1\%) patients had a picture of CT4. $60 \%$ of patients in group 3 , $22.2 \%$ of patients in group 2 , and $8.3 \%$ of patients in group 1 had severe CT4 lung damage. The damage of the lung parenchyma, more than $90 \%$, was observed only in group 3 (Figure 3 ).

History of arterial hypertension was detected in 22 (59.5\%) patients. Among them, 12 (52.9\%) patients developed AKI, 2 (9.1\%) required HD. Cardiovascular diseases were observed in 12 (32.4\%) patients: 8 patients with exertional angina / postinfarction cardiosclerosis; 4 patients with atrial fibrillation, 2 patients with congestive heart disease. Among patients with CVD, 9 (75\%) patients developed AKI, and 1 (8.3\%) patient required hemodialysis. 
Type 2 diabetes mellitus (DM) was also diagnosed in 12 (32.4\%) patients: 10 (83.3\%) patients developed AKI, 2 (16.7\%) patients required hemodialysis. AKI prevalence was significantly higher in patients with a history of diabetes mellitus and did not depend on the arterial hypertension or cardiovascular diseases in our study (Figure 4).

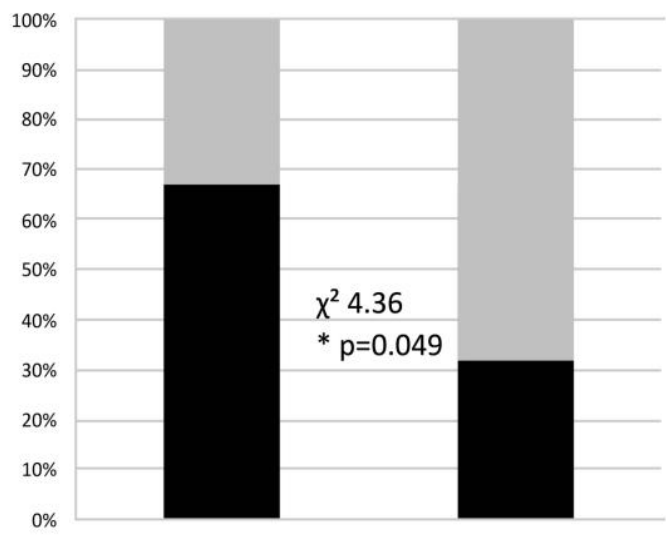

Diabetes mellitus (+) Diabetes mellitus (-)

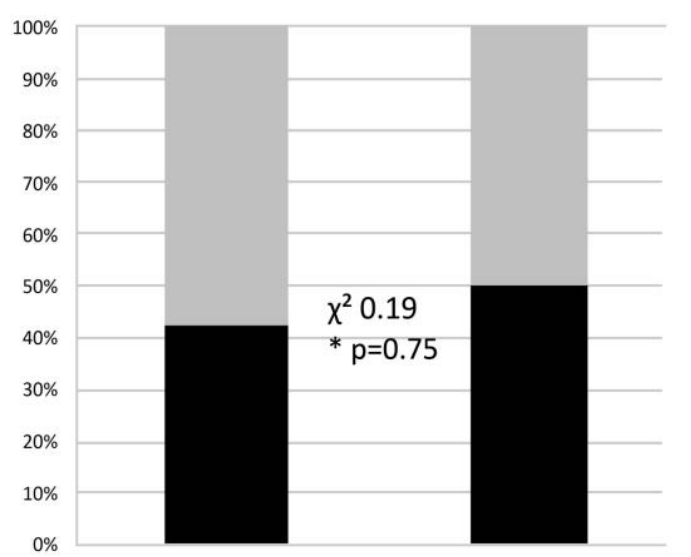

Arterial hypertension (+) Arterial hypertension (-)

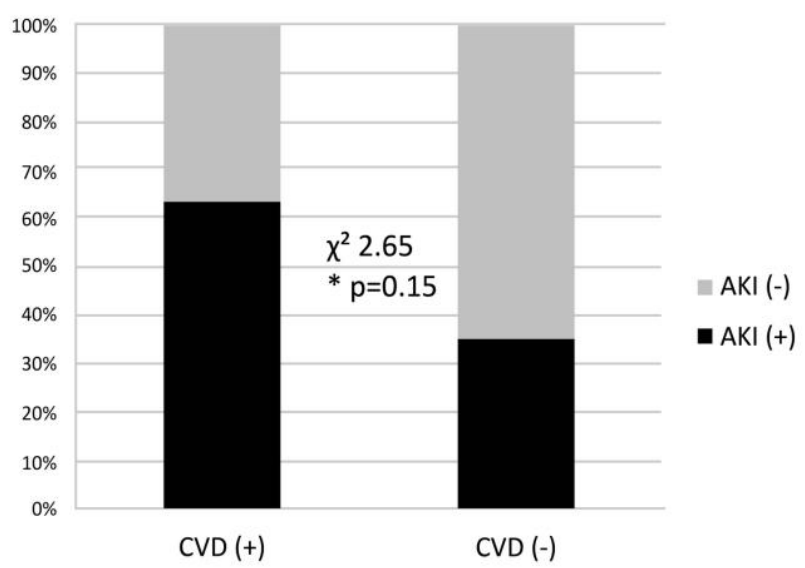

Figure 4. Underlying conditions critically ill patients with COVID-19 *p - Fisher exact $p$, two-tailed.
Table 1. Factorial analysis of AKI risk factors

\begin{tabular}{lcccc}
\hline & & \multicolumn{3}{c}{ Factor } \\
& -1 & 2 & 3 & 4 \\
\hline Age & 0.773 & -0.413 & -0.482 & 0.004 \\
Arterial hypertension & 0.945 & -0.058 & -0.008 & -0.321 \\
Cardiovascular diseases & 0.945 & -0.058 & -0.008 & -0.321 \\
Leukocytes (max) & 0.094 & -0.072 & 0.973 & 0.197 \\
Procalciotonin & -0.239 & -0.313 & 0.822 & 0.411 \\
C-reactive protein & -0.352 & -0.098 & 0.131 & 0.922 \\
Fibrinogen & -0.296 & 0.438 & 0.258 & 0.809 \\
D-dimer & 0.228 & 0.568 & 0.747 & 0.258 \\
Platelets & 0.099 & -0.955 & -0.090 & 0.266 \\
\hline
\end{tabular}

Rotated component matrix, Varimax rotation with Kaizer normalization.

Table 2. Multiple linear regression analysis of AKI risk factors

\begin{tabular}{|c|c|c|c|c|c|}
\hline \multirow[t]{2}{*}{ Model } & \multicolumn{2}{|c|}{$\begin{array}{c}\text { Unstandardized } \\
\text { regression coefficients }\end{array}$} & \multirow{2}{*}{$\begin{array}{c}\text { Standardized } \\
\text { regression coefficients } \\
\beta\end{array}$} & \multirow[t]{2}{*}{$m$} & \multirow[t]{2}{*}{$p$} \\
\hline & $B$ & Standard error & & & \\
\hline C-reactive protein & 0.001 & 0.001 & 0.441 & 2.061 & 0.047 \\
\hline Platelets & -0.002 & 0.001 & -0.581 & -2.626 & 0.013 \\
\hline Age & 0.010 & 0.003 & 0.872 & 3.028 & 0.005 \\
\hline
\end{tabular}

Table 3. Multiple linear regression analysis of mortality

\begin{tabular}{|c|c|c|c|c|c|}
\hline \multirow[t]{2}{*}{ Model } & \multicolumn{2}{|c|}{$\begin{array}{l}\text { Unstandardized } \\
\text { regression coefficients }\end{array}$} & \multirow{2}{*}{$\begin{array}{c}\text { Standardized } \\
\text { regression oefficients } \\
\text { Beta }\end{array}$} & \multirow[t]{2}{*}{$t$} & \multirow[t]{2}{*}{$p$} \\
\hline & B & Std. error & & & \\
\hline Constant & 1.816 & 0.353 & & 5.138 & 0.000 \\
\hline Proteinuria & 0.302 & 0.188 & 0.248 & 1.605 & 0.120 \\
\hline AKI & 0.237 & 0.099 & 0.370 & 2.398 & 0.023 \\
\hline $\mathrm{CT}$ grades & 0.240 & 0.100 & 0.363 & -2.401 & 0.023 \\
\hline
\end{tabular}

\section{Renal disorders risk factors}

Based on factor analysis, four risk factors were extracted that explained the development of acute renal injury in critically ill patients with COVID-19. These factors include 1) age over 60 years with other underlying conditions (existing arterial hypertension and cardiovascular diseases), 2) signs of hypercoagulation and DIC (increased D-Dimer level $>4000 \mathrm{ng} / \mathrm{ml}$ and decreased platelet count) 3) signs of bacterial infection (leukocytosis and increased procalcitonin level more than $0.98 \mathrm{ng} / \mathrm{ml}), 4$ ) inflammation markers (CRP $>240 \mathrm{mg} / \mathrm{l}$ and fibrinogen). (Table 1, Supplementary Material, Table 5), (Figure 5).

According to the regression analysis, independent risk factors for the development of AKI in patients with COVID-19 were determined - age more than 60 years, increased CRP level, and decreased platelet count (Table 2). Treatment with antiviral drugs, nephrotoxic antibiotics, and administration of dexamethasone or tocilizumab were not associated with an increased/decreased risk of developing AKI in our study.

The factors associated with proteinuria $\geq 1 \mathrm{~g} /$ day were inflammation markers (CRP, procalcitonin, and leukocytosis) and hypercoagulability (D-dimer, low platelets count) in combination with older age (Supplementary Material, Table 2). Age was found to be significant for proteinuria development in multiple regression analysis (Supplementary Material, Table 3). For hematuria, the D-dimer levels and low white blood cell counts were significant (Supplementary Material, Table 4).

$13(76.47 \%)$ of the 17 patients did not survive. In the patients without AKI $4(20 \%)$ patients did not survive neither. Odds ratio 13.00 [2.57-65.8], $p<0.001$. The risk of mortality in patients admitted to the intensive care unit was associated with the AKI and the severity of lung damage (Table 3 ). 


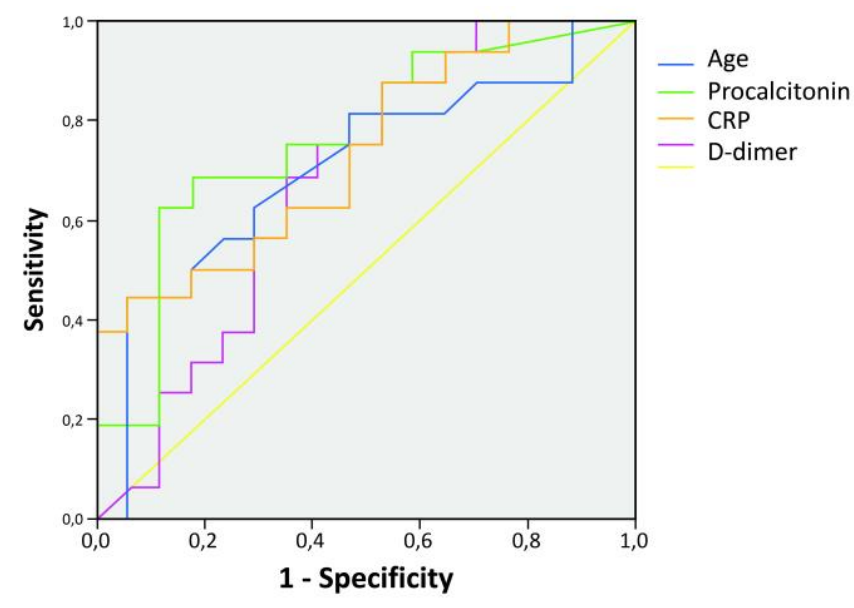

\begin{tabular}{|l|l|l|}
\hline & Sensitivity & Specificity \\
\hline Age $>60$ years & 63.0 & 70.6 \\
\hline Procalcitonin $>0.98 \mathrm{ng} / \mathrm{ml}$ & 70.0 & 82.4 \\
\hline CRP $>240 \mathrm{mg} / \mathrm{l}$ & 63.0 & 65.0 \\
\hline D-dimer $>4000 \mathrm{ng} / \mathrm{ml}$ & 69.0 & 65.0 \\
\hline
\end{tabular}

Figure 5. ROC-analysis for AKI risk factors in critically ill patients with COVID-19.

\section{Discussion}

Kidney damage is a common complication of COVID-19, especially in critically ill patients. According to recent studies, AKI has been reported in up to $29 \%$ of critically-ill patients with SARSCoV-2 infection [2-6]. In our study, kidney damage with the development of AKI was observed in a more significant percentage of cases, specifically in $45.9 \%$ of patients, and almost a quarter of the total number of patients in the ICU had AKI stage 3, which required HD. AKI in COVID-19 has a complex multifactorial genesis. Several main factors can lead to AKI: direct viral damage, cytokine storm, thrombotic microangiopathy, and ischemic/hypoxic damage, etc. [9]. Equivalently to kidney dysfunction defined by a creatinine level increase in the blood serum, patients might also have abnormal changes in the urine. In our study, such changes were noted in all patients in ICU. Proteinuria was observed in all critically ill patients. Proteinuria up to $1 \mathrm{~g} / \mathrm{l}$ was detected in $58 \%$ of patients; hematuria was detected in $44 \%$ of patients. The factors associated with proteinuria $\geq 1 \mathrm{~g}$ per day were inflammation and hypercoagulability. Older age turned out to be an independent factor, which is possibly associated with a more severe infection.

According to studies, up to $60 \%$ of patients with COVID-19 present moderate proteinuria [4], nephrotic syndrome rarely develops $[10,11]$. The onset of proteinuria is thought to be related to the direct damaging effect of SARS-CoV-2 on kidney cells. This theory was confirmed by kidney tissue histological examination obtained from autopsy material [12]. Initially, diffuse injury to the proximal convoluted tubules with loss of brush border was reported along with the vacuolar degeneration, which led to tubular necrosis in some cases. Viral particles were detected in podocytes and tubular epithelium by electron microscopy and immunohistochemical examination. This observation confirms the theory of the virus's ability to enter the kidney tissue cells, causing them direct damage. Epithelial cells with viral particles in the replication stage were found [12]. Besides, in some studies, SARSCoV-2 virus RNA was also detected in urine [13]. Proteinuria can also be caused by RAAS activation. It is thought that the accumulation of angiotensin II may be responsible for nephrin endocytosis and subsequently increased glomerular permeability with proteinuria [14]. Even though changes in urine are insignificant in most cases, the appearance of proteinuria or hematuria is associated with higher mortality in patients [15]. In our study, hematuria was associated with an increase in D-dimer levels and the low levels of blood leukocytes. It can be assumed that the virus and hypercoagulable state can influence the change in urinary sediment. Nevertheless hematuria should be interpreted with caution in patients in ICU, since the appearance of erythrocytes in the urine may be due to other reasons, such as a urethral catheter.

In our study, the majority (more than $60 \%$ ) of patients had severe electrolyte disturbances (hypokalemia, hyponatremia, hypomagnesemia, hypophosphatemia), which may be associated with tubular damage due to the direct toxic effect of high cytokines concentrations leading to the tubular dysfunction or tubular necrosis SARS-CoV-2 virus recruits macrophages CD68+ predominantly into the tubulointerstitium, suggesting that proinflammatory cytokines derived from macrophages induce tubular damage [16]. Our data are consistent with a study showing that hypokalemia occurs in $93 \%$ of patients at admissions. The authors suggest that increased kaliuresis is related to increased angiotensin II levels [17], diarrhea, uptake of diuretics and other nephrotoxic drugs [7]; however, in our study, electrolyte disturbances were not reliably associated with the development of AKI, loop diuretics or other drugs uptake. Moreover, in our study, tubular disorders were significantly more frequent in patients with a lower leukocyte count. It suggests that these processes are associated with the activity of the virus itself and its action on both blood leukocytes and tubular epithelial cells.

It was confirmed that SARS-CoV-2 causes kidney damage through immune cell activation and cytokine storm [Ошибка! Закладка не определена., 18]. Macrophages and neutrophils produce high levels of proinflammatory cytokines - interleukin (IL) $1 \beta, \mathrm{IL}-6$, and tumor necrosis factor-alpha (TNF $\alpha$ ) that might directly damage the kidney cells [19]. The cytokine storm is characterized by an immune system hyperactivation and the excess amount production of cytokines, which plays a crucial role in kidney damage. The laboratory signs of a cytokine storm include elevated levels of C-reactive protein (CRP), interleukin-6 (IL-6), ferritin, fibrinogen, lactate dehydrogenase (LDH), and the soluble IL-2 receptor $[19,20]$. In our study, the inflammatory syndrome with a CRP level increase of more than $200 \mathrm{mg} / \mathrm{L}$ was more notable in patients with severe AKI. The levels of other inflammatory proteins, ferritin, and fibrinogen, which were significantly increased in all patients, did not differ significantly between the groups. We showed that patients with severe AKI stage 3 were also characterized by a significant increase in the procalcitonin level more than 10 times, indicating the enhancement of a bacterial infection, including nosocomial sepsis. Given that patients in the group with severe AKI had a large area of pulmonary parenchyma lesions, viral-bacterial associations can aggravate systemic hypoxia and worsen the course of nephropathy. In addition, hypoxia enhances hypercoagulation by increasing platelet aggregation, fibrinogen, thrombopoietin and thrombin hyperproduction, and a decrease in the production of 
anticoagulants (antithrombin III, an inhibitor of plasminogen activator) [21-24].

Severe hypercoagulability with an increase in D-dimer occurred in all patients with impaired renal function. D-dimer levels were elevated prior to the development of AKI and continued to rise as renal function worsened. Also, there was a decrease in platelet count in group 3, which we consider as a consequence of DIC's joint development in which the increased consumption of platelets and coagulation factors occur. The consumption of fibrinogen, though, is less significant. Since it is a protein of the acute phase of inflammation, and it is significantly increased in COVID-19 and is considered a less sensitive marker of DIC [25]. According to some reports, caucasian COVID-19 patients on low molecular weight heparin thromboprophylaxis rarely develop overt disseminated intravascular coagulation (DIC) [26]. One study reported DIC only in $2.1 \%$ of 388 patients, with no bleeding complications [27]. However, in study of Zhou F et al. $50 \%$ non-survivors had evidence of coagulopathy defined as a 3 second prothrombin time increase or a 5 -second increase in activated partial thromboplastin time [Ошибка! Закладка не определена.]. It was also shown that thrombocytopenia is common in patients with COVID-19, and it is associated with increased risk of in-hospital mortality [28]. Apparently, the development of DIC plays a crucial role in the progression of nephropathy and the development of severe forms of renal damage.

Activated immune cells contribute to the extrinsic and intrinsic coagulation pathways and immunotrombosis (so-called thromboinflammation) by McGonagle et al. and was supported by Henry BM et al. [29, 30]. Besides, there was evidence of glomerular ischemia and fibrin thrombi within the glomerular capillary loops and strong complement C5b-9 deposition in the renal tubules [31, 32]. Local thrombotic microangiopathy in the kidney appears to be another crucial factor in the progression of AKI in COVID-19 patients. Autopsies of patients who died from COVID-19 revealed multiple hyaline thrombi in small blood vessels, mononuclear and lymphocytic infiltration, endothelial detachment, and inflammation of the vascular wall [25]. Endothelitis and endotheliocytes apoptosis develop, leading to the activation of macrophages and neutrophils, which produce inflammatory mediators. Local intrarenal TMA can develop as a result of direct viral damage to the endothelium, or through exposure to type 2 ACE receptors, which are also present on the surface of endothelial cells of large and small arteries [25, 33].

In our study, the occurrence of renal dysfunction was also higher in elderly patients and patients with concomitant disease such as diabetes mellitus, which is compatible with the data of other studies [2, 3, 33-35]. The independent risk factors for the development of severe AKI in critically ill patients were age over 60 years, an increase in CRP level over $240 \mathrm{mg} / \mathrm{L}$, D-dimer level over $4000 \mathrm{ng} / \mathrm{ml}$, and a decrease in platelet count. Therefore, the cytokine storm complicated with the DIC is the main factor in kidney damage and prognosis in these COVID-19 patients. In turn, the acute kidney injury and the severity of lung damage were associated with mortality in these patients.

This study has some limitations. The groups of patients were not significant. The patients received various treatment strategies. Therefore, the relationship between AKI development and the treatment requires further study with a more significant number of patients.

\section{Conclusion}

Kidney damage was observed in all critically ill patients with COVID-19. More than $60 \%$ of patients had tubular disorders with electrolyte imbalance. Half of all examined patients developed AKI, requiring hemodialysis in $21.6 \%$ of cases. The factors associated with AKI were severe lung damage and concomitant disease such as diabetes mellitus. The independent risk factors for developing severe AKI in critically ill patients were elderly age, a cytokine response with a high CRP level.

\section{Conflict of Interest Statement}

The authors do not have any conflicts of interest to declare.

\section{Funding}

None

\section{Ethical approva}

All procedures performed in studies involving human participants were in accordance with the ethical standards of the institutional research committee and with the 1964 Helsinki declaration and its later amendments or comparable ethical standards.

For this type of study, formal consent is not required.

\section{References}

1. Li H, Liu SM, Yu XH, Tang SL, Tang CK. Coronavirus disease 2019 (COVID-19): current status and future perspectives. Int J Antimicrob Agents 2020; 55(5): 105951. https://doi.org/10.1016/j.ijantimicag.2020.105951.

2. Wang D, Hu B, Hu C, Zhu F, Liu X, Zhang J, et al. Clinical characteristics of 138 hospitalized patients with 2019 novel coronavirus-infected pneumonia in Wuhan, China. JAMA 2020; 323(11): 1061-1069. https://doi.org/10.1001/jama.2020.1585

3. Huang C, Wang Y, Li X, Ren L, Zhao J, Hu Y, et al. Clinical features of patients infected with 2019 novel coronavirus in Wuhan, China. Lancet 2020; 395(10223): 497-506. https://doi.org/10.1016/s01406736(20)30183-5.

4. Li Z, Wu M, Yao J, Guo J, Liao X, Song S, et al. Caution on kidney dysfunctions of 2019-nCoV patients. MedRxiv. The preprint server for health $\quad$ sciences 2020 : $1-25$. https://doi.org/10.1101/2020.02.08.20021212.

5. Zhou F, Yu T, Du R, Fan G, Liu Y, Liu Z, et al. Clinical course and risk factors for mortality of adult inpatients with COVID-19 in Wuhan, China: a retrospective cohort study. Lancet 2020; 395(10229): 1054 1062. https://doi.org/10.1016/s0140-6736(20)30566-3.

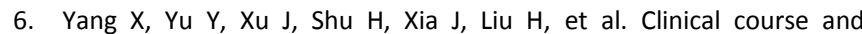
outcomes of critically ill patients with SARS-CoV-2 pneumonia in Wuhan, China: a single-centered, retrospective, observational study. Lancet Respir Med 2020; 8(5): 475-481. https://doi.org/10.1016/s2213-2600(20)30079-5.

7. Gabarre P, Dumas G, Dupont T, Darmon M, Azoulay E, Zafrani L. Acute kidney injury in critically ill patients with COVID-19. Intensive Care Medicine 2020; 46(7): 1339-1348. https://doi.org/10.1007/s00134020-06153-9.

8. KDIGO Clinical Practice Guideline for Acute Kidney Injury. Kidney International Supplements 2012; 2(1); 138 p. https://kdigo.org/wpcontent/uploads/2016/10/KDIGO-2012-AKI-Guideline-English.pdf.

9. Ronco C, Reis T, Husain-Syed F. Management of acute kidney injury in patients with COVID-19. Lancet Respir Med 2020; 8(7): 738-742. https://doi.org/10.1016/S2213-2600(20)30229-0.

10. Larsen CP, Bourne TD, Wilson JD, Saqqa O, Sharshir MA. Collapsing glomerulopathy in a patient with coronavirus disease 2019 (COVID-19). 
Kidney Int Rep 2020; 5(6): 935-939. https://doi.org/10.1016/j.ekir.2020.04.002.

11. Kissling S, Rotman S, Gerber C, Halfon M, Lamoth F, Comte D, et al. Collapsing glomerulopathy in a COVID-19 patient. Kidney Int 2020; 98(1): 228-239. https://doi.org/10.1016/j.kint.2020.04.006.

12. Farkash EA, Wilson AM, Jentzen JM. Ultrastructural Evidence for Direct Renal Infection with SARS-CoV-2. J Am Soc Nephrol 2020; 31(8): 16831687. https://doi.org/10.1681/asn.2020040432.

13. Wang L, Li X, Chen H, Yan S, Li D, Li Y, et al. Coronavirus disease 19 infection does not result in acute kidney injury: an analysis of 116 hospitalized patients from Wuhan, China. Am J Nephrol 2020; 51(5): 343-348. https://doi.org/10.1159/000507471.

14. Martínez-Rojas MA, Vega-Vega O, Bobadilla NA. Is the kidney a target of SARS-CoV-2? Am J Physiol Renal Physiol 2020; 318(6): F1454-F1462. https://doi.org/10.1152/ajprenal.00160.2020.

15. Cheng $Y$, Luo $R$, Wang $K$, Zhang $M$, Wang $Z$, Dong $L$, et al. Kidney disease is associated with in-hospital death of patients with COVID-19. $\begin{array}{llll}\text { Kidney Int 2020; 97(5), } & \text { 829-838. }\end{array}$ https://doi.org/10.1016/j.kint.2020.03.005.

16. Diao B, Wang $C$, Wang $R$, Feng $Z$, Zhang J, Yang $H$, et al. Human kidney is a target for novel severe acute respiratory syndrome coronavirus 2 infection. Nat Commun. 2021; 12(1): 2506. https://doi.org/10.1038/s41467-021-22781-1.

17. Chen D, Li X, Song Q, Hu C, Su F, Dai J, et al. Hypokalemia and clinical implications in patients with coronavirus disease 2019 (COVID-19). MedRxiv. The preprint server for health sciences 2020: 1-22. https://doi.org/10.1101/2020.02.27.20028530.

18. Henrya BM, Vikseb J, Benoitc C, Favaloro EJ, Lippi G. Hyperinflammation and derangement of renin-angiotensinaldosterone system in COVID-19: A novel hypothesis for clinically suspected hypercoagulopathy and microvascular immunothrombosis. Clin Chim Acta 2020; 507: 167-173. https://doi.org/10.1016/j.cca.2020.04.027.

19. Fardet L, Galicier L, Lambotte O, Marzac C, Aumont C, Chahwan D, et al. Development and validation of the HScore, a score for the diagnosis of reactive hemophagocytic syndrome. Arthritis Rheum 2014; 66(9): 2613-2620. https://doi.org/10.1002/art.38690.

20. Schulert GS, Grom AA. Pathogenesis of macrophage activation syndrome and potential for cytokine-directed therapies. Annu Rev Med 2015; 66: 145-159. https://doi.org/10.1146/annurev-med061813-012806.

21. Gross O, Moerer O, Weber M, Huber TB, Scheithauer S. COVID-19associated nephritis: early warning for disease severity and complications? Lancet 2020; 395(10236): e87-e88. https://doi.org/10.1016/s0140-6736(20)31041-2.

22. Su H, Yang $M$, Wan C, Yi LX, Tang F, Zhu HY, et al. Renal histopathological analysis of 26 postmortem findings of patients with COVID-19 in China. Kidney Int 2020; 98(1): 219-227. https://doi.org/10.1016/j.kint.2020.04.003.

23. Cuevas Tascón G, Salazar Chiriboga DE, Lorente Ramos R, Díaz Díaz D, Rodríguez Ruiz C, Procaccini FL, et al. Renal infaction in a patient with COVID-19. Nefrologia (Engl Ed) 2020; 41(1): 84-87. Spanish. https://doi.org/10.1016/j.nefro.2020.04.008

24. Han H, Yang L, Liu R, Liu F, Wu KL, Li J, et al. Prominent changes in blood coagulation of patients with SARS-CoV-2 infection. Clin Chem Lab Med 2020; 58(7): 1116-1120. https://doi.org/10.1515/cclm-20200188.

25. Zhang Y, Cao W, Xiao M, Li YJ, Yang Y, Zhao J, et al. Clinical and coagulation characteristics of 7 patients with critical COVID-2019 pneumonia and acro-ischemia. Zhonghua Xue Ye Xue Za Zhi 2020; 41(0): E006. Chinese. https://doi.org/10.3760/cma.j.issn.02532727.2020.0006.

26. Fogarty H, Townsend L, Ni Cheallaigh C, Bergin C, Martin-Loeches I, Browne $\mathrm{P}$, et al. More on COVID-19 coagulopathy in Caucasian patients. $\mathrm{Br} J$ Haematol 2020; 189(6): 1060-1061. https://doi.org/10.1111/bjh.16791.

27. Lodigiani C, lapichino G, Carenzo L, Cecconi M, Ferrazzi P, Sebastian T, et al. Venous and arterial thromboembolic complications in COVID-19 patients admitted to an academic hospital in Milan, Italy. Thromb Res 2020; 191: 9-14. https://doi.org/10.1016/j.thromres.2020.04.024.

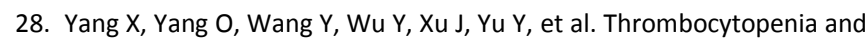
its association with mortality in patients with COVID-19. J Thromb Haemost 2020; 18(6): 1469-1472. https://doi.org/10.1111/jth.14848.

29. Jackson SP, Darbousset R, Schoenwaelder SM. Thromboinflammation: challenges of therapeutically targeting coagulation and other host defense mechanisms. Blood 2019; 133(9): 906-918. https://doi.org/10.1182/blood-2018-11-882993.

30. McGonagle D, O'Donnell JS, Sharif K, Emery P, Bridgewood C. Immune mechanisms of pulmonary intravascular coagulopathy in COVID-19 pneumonia. Lancet Rheumatol 2020; 2(7): e437-e445. https://doi.org/10.1016/s2665-9913(20)30121-1.

31. Cheng $Y$, Luo $R$, Wang $K$, Zhang $M$, Wang $Z$, Dong $L$, et al, Kidney impairment is associated with in-hospital death of COVID-19 patients. MedRxiv. The preprint server for health sciences 2020: 1-21. https://doi.org/10.1101/2020.02.18.20023242.

32. Su H, Yang M, Wan C, Yi LX, Tang F, Zhu HY, et al. Renal histopathological analysis of 26 postmortem findings of patients with COVID-19 in China. Kidney Int 2020; 98(1), 219-227. https://doi.org/10.1016/j.kint.2020.04.003.

33. Pei G, Zhang Z, Peng J, Liu L, Zhang C, Yu C, et al. Renal Involvement and Early Prognosis in Patients with COVID-19 Pneumonia. J Am Soc Nephrol 2020; 31(6): 1157-1165. https://doi.org/10.1681/ASN.2020030276.

34. Xu XW, Wu XX, Jiang XG, Xu KJ, Ying $L, M a C L$, et al. Clinical findings in a group of patients infected with the 2019 novel coronavirus (SARSCov-2) outside of Wuhan, China: retrospective case series. BMJ 2020; 368: m606. https://doi.org/10.1136/bmj.m606.

35. Zhang JJ, Dong X, Cao YY, Yuan YD, Yang YB, Yan YQ, et al. Clinical characteristics of 140 patients infected with SARS-CoV-2 in Wuhan, China. Allergy 2020; 75(7): 1730-1741. https://onlinelibrary.wiley.com/doi/full/10.1111/all.14238.

\section{Authors:}

Diana K. Sarkisian - Professor Assistant, Department of Internal Medicine, Faculty of Medicine, Lomonosov Moscow State University, Moscow, Russia. https://orcid.org/0000-0001-8632-6973.

Natalia V. Chebotareva - PhD, MD, Professor, Nephology Department, Sechenov First Moscow State Medical University (Sechenov University), Moscow, Russia. https://orcid.org/0000-0003-2128-8560.

Valerie McDonnell - Professor Assistant, Department of Internal Medicine, Faculty of Medicine, Lomonosov Moscow State University, Moscow, Russia. https://orcid.org/0000-0003-3270-2691.

Armen V. Oganesyan - PhD, Head of Intensive Care Unit, ZAO Group of Companies Medsi Clinical Hospital No.1, Moscow, Russia. https://orcid.org/0000-0002-3979-9652.

Tatyana N. Krasnova - PhD, Professor, Department of Internal Medicine, Faculty of Medicine, Lomonosov Moscow State University, Moscow, Russia. https://orcid.org/0000-0001-6175-1076.

Egor A. Makarov - PhD, Professor Assistant, Faculty of Medicine, Moscow State University, Moscow, Russia. https://orcid.org/0000-0002-2387-9930. 


\section{Supplementary Material}

Table 1. Multiple linear regression analysis of tubular dysfuncton

\begin{tabular}{|c|c|c|c|c|c|}
\hline \multirow[t]{2}{*}{ Model } & \multicolumn{2}{|c|}{$\begin{array}{l}\text { Unstandardized } \\
\text { regression coefficients }\end{array}$} & \multirow{2}{*}{$\begin{array}{c}\text { Standardized regression } \\
\text { coefficients } \\
\text { Beta }\end{array}$} & \multirow[t]{2}{*}{$t$} & \multirow[t]{2}{*}{$p$} \\
\hline & B & Std. error & & & \\
\hline (Constant) & 1.015 & 0.135 & & 7.492 & 0.000 \\
\hline Leukocytes (min) & -0.055 & 0.016 & -0.499 & -3.409 & 0.002 \\
\hline
\end{tabular}

Table 2. Factorial analysis for proteinuria $\geq 1 \mathrm{~g} /$ day in critically ill patients

\begin{tabular}{lcc}
\hline & \multicolumn{3}{c}{ Factor } \\
\hline Leukocytes (max) & 1 & 2 \\
C-reactive protein & 0.781 & -0.219 \\
Procalciotonin & 0.816 & -0.117 \\
D-dimer & 0.892 & -0.286 \\
Trombocytes & 0.463 & 0.731 \\
Age & -0.554 & -0.535 \\
\hline
\end{tabular}

Table 3. Multiple linear regression analysis of proteinuria $\geq 1 \mathrm{~g} / \mathrm{day}$

\begin{tabular}{lccccc}
\hline Model & \multicolumn{2}{c}{ Unstandardized } & Standardized regression \\
regression coefficients & coefficients & $t$ & $p$ \\
\cline { 1 - 4 } & B & Std. error & Beta & & \\
\hline Age & 0.009 & 0.001 & 0.760 & 6.925 & 0.000 \\
\hline
\end{tabular}

Table 4. Multiple linear regression analysis of hematuria

\begin{tabular}{|c|c|c|c|c|c|}
\hline \multirow[t]{2}{*}{ Model } & \multicolumn{2}{|c|}{$\begin{array}{l}\text { Unstandardized } \\
\text { regression coefficients }\end{array}$} & \multirow{2}{*}{$\begin{array}{c}\text { Standardized } \\
\text { regression coefficients } \\
\text { Beta }\end{array}$} & \multirow[t]{2}{*}{$t$} & \multirow[t]{2}{*}{$p$} \\
\hline & B & Std. error & & & \\
\hline (Constant) & 1.407 & 0.281 & & 5.009 & 0.000 \\
\hline Leukocytes (min) & -0.058 & 0.029 & -0.310 & -2.036 & 0.050 \\
\hline D-dimer & $3.232 \mathrm{E}-5$ & 0.000 & 0.379 & 2.487 & 0.018 \\
\hline
\end{tabular}

Table 5. Total Variance Explained for the AKI model

\begin{tabular}{|c|c|c|c|c|c|c|c|c|c|}
\hline \multirow{2}{*}{ Component } & \multicolumn{3}{|c|}{ Initial eigenvalues } & \multicolumn{3}{|c|}{ Extraction Sums of Squared Loadings } & \multicolumn{3}{|c|}{ Rotation of Squared Loadings } \\
\hline & Total & $\%$ Variance & Cumulative\% & Total & $\%$ Variance & Cumulative \% & Total & $\%$ Variance & Cumulative \% \\
\hline 1 & 4.582 & 45.816 & 45.816 & 4.582 & 45.816 & 45.816 & 2.891 & 28.907 & 28.907 \\
\hline 2 & 2.390 & 23.899 & 69.715 & 2.390 & 23.899 & 69.715 & 2.531 & 25.313 & 54.220 \\
\hline 3 & 1.861 & 18.608 & 88.322 & 1.861 & 18.608 & 88.322 & 2.508 & 25.076 & 79.297 \\
\hline 4 & 1.168 & 11.678 & 100.000 & 1.168 & 11.678 & 100.000 & 2.070 & 20.703 & 100.000 \\
\hline 5 & $4.745 \mathrm{E}-16$ & $4.745 \mathrm{E}-15$ & 100.000 & & & & & & \\
\hline 6 & $2.556 \mathrm{E}-16$ & $2.556 \mathrm{E}-15$ & 100.000 & & & & & & \\
\hline 7 & $2.008 \mathrm{E}-16$ & $2.008 \mathrm{E}-15$ & 100.000 & & & & & & \\
\hline 8 & $-1.489 E-47$ & $-1.489 \mathrm{E}-46$ & 100.000 & & & & & & \\
\hline 9 & $-1.549 E-17$ & $-1.549 \mathrm{E}-16$ & 100.000 & & & & & & \\
\hline 10 & $-3.811 \mathrm{E}-16$ & $-3.811 \mathrm{E}-15$ & 100.000 & & & & & & \\
\hline
\end{tabular}

Extraction Method: Principal Axis Factoring 